\title{
Cancer predisposing BARD1 mutations in breast-ovarian cancer families
}

\author{
Magdalena Ratajska1*, Magdalena Matusiak', Izabela Brożek', Maciej Stukan, Marcin Śniadecki², Jarosław Dębniak, \\ Dariusz Wydra², Janusz Limon ${ }^{1}$ \\ From Annual Conference on Hereditary Cancers 2012 \\ Szczecin, Poland. 30-31 August 2012
}

BARD1 was identified as a protein interacting with BRCA1 - the heterodimer formed by BRCA1 and BARD1 acts in DNA repair, RNA processing, transcription and cell cycle regulation. BARD1 has also BRCA1-independent functions like mediating p53-dependent apoptosis. Additionally, BARD1 mRNA isoforms were found to be highly expressed in most human gynecological cancers.

We report 17 different $B A R D 1$ variants, four of which were suspected to be pathogenic, including a novel substitution (c.1361C $>\mathrm{T}$ ) leading to amino acid change in highly conserved ankirin domain motif, a splice mutation (c.1315-2A/G) resulting in exon 5 skipping and a silent change (c.1977A/G) which alters several ESE motifs in exon 10, and results in a transcript lacking exons 2-9. Finally we identified two unrelated patients carrying truncating nonsense mutation in exon 8 (c.1690C $>$ T).

Our findings suggest that BARD1 mutations may be regarded as cancer risk alleles and warrant further investigation to determine their actual contribution to nonBRCA1/2 breast and ovarian cancer families.

\footnotetext{
Author details

'Department of Biology and Genetics, Medical University of Gdansk, Gdansk, Poland. ²Department of Gynecology, Gynecologic Oncology and Gynecologic Endocrinology, Medical University in Gdańsk, Poland.

Published: 10 December 2012

doi:10.1186/1897-4287-10-S4-A10

Cite this article as: Ratajska et al:: Cancer predisposing BARD1 mutations in breast-ovarian cancer families. Hereditary Cancer in Clinical Practice 2012 10(Suppl 4):A10
}

'Department of Biology and Genetics, Medical University of Gdansk, Gdansk, Poland

Full list of author information is available at the end of the article
Submit your next manuscript to BioMed Central and take full advantage of:

- Convenient online submission

- Thorough peer review

- No space constraints or color figure charges

- Immediate publication on acceptance

- Inclusion in PubMed, CAS, Scopus and Google Scholar

- Research which is freely available for redistribution

Submit your manuscript at www.biomedcentral.com/submit
() Biomed Central 